\title{
Pastor Comín, J. J. (2019). “Más vale trocar...” Cinco viajes musicales por la literatura de la España moderna (1496-1645). Vigo: Editorial Academia del Hispanismo, 350 pp. ISBN: 978-84-17696-23-8.
}

Las relaciones entre música y literatura constituyen un apasionante terreno que no siempre ha sido explorado con el rigor y los instrumentos necesarios que exigen ambas disciplinas. Es muy frecuente encontrar estudios de naturaleza musicológica que cuando se enfrentan a la naturaleza de los textos literarios con los que las músicas conviven se muestran titubeantes en el ámbito filológico, alejados de sólidos marcos teóricos desde los que fijar una perspectiva y en buena medida no demasiado diestros en la utilización de los instrumentos lingüísticos, estilísticos, históricos y estéticos que permitan examinar con solvencia el análisis de las relaciones que la palabra mantiene con su encarnadura musical. De igual modo, es frecuente encontrar estudios de naturaleza filológica que o bien ignoran la trascendencia que tiene el hecho musical como intérprete del corpus literario, o bien adolecen de las más básicas herramientas que propicia el análisis musical y naufragan en una amalgama de metáforas o en un aluvión de documentación histórica que en nada contribuyen a revelar los sentidos de las obras que contemplan.

Felizmente, este no es el caso del libro que nos ocupa. Su autor, Juan José Pastor Comín, concita un doble perfil tanto en su formación académica como en su desarrollo profesional lo suficientemente bien pertrechado como para enfrentarse con solvencia a los retos de una investigación interdisciplinar de estas características. Doctor en Filología Hispánica y Profesor Titular de Universidad en el área de Música de la Universidad de Castilla-La Mancha, co-dirige el Centro de Investigación y Documentación Musical (CIDoM), Unidad Asociada al CSIC. Conocido por sus libros anteriores sobre Cervantes y el fenómeno musical -Cervantes: Música y Poesía. El hecho musical en el pensamiento lírico cervantino (2007), o Loco, trovador y cortesano: bases materiales de la expresión musical en Cervantes (2009)regresa a la literatura del Siglo de Oro y su articulación a través de la música precisamente en el contexto de las investigaciones que dirige, concedidas por el antiguo Ministerio de Economía y Competitividad (Proyecto I+D+i HAR2017-86-039-C2-2-P, El patrimonio musical de la España moderna (siglos XVII y XVIII): recuperación, digitalización, análisis y estructuras retóricas de los discursos musicales"), así como por el recientemente concedido en la convocatoria de Acciones de Dinamización de Redes de Investigación (RED2018-102342T, Música, Literatura y poder en la España moderna: estudios interdisciplinares).

Escrito con una nitidez precisa y cuidado en todo momento en la respiración de la frase, la lectura de esta propuesta se hace amable no solo por los contenidos ofrecidos sino por el cauce discursivo que presenta. Estructurado como un viaje en cinco jornadas, abrirá 
y cerrará la aventura académica con un marco prologal y epigonal de notable riqueza hermenéutica y con una clara exposición de sus propósitos y conclusiones: a saber, la necesaria cooperación interdisciplinar que se requiere para comprender con profundidad los fenómenos artísticos híbridos que evidencian la mixtura genética de ambas artes. Bien desde el ámbito del teatro, de la creación lírica o narrativa, el fenómeno literario necesita ser contemplado en su relación con la realidad musical que incorpora, recrea, nutre y resuena entre sus líneas, del mismo modo que la técnica y las decisiones compositivas del compositor deben ser evaluadas desde su posición como intérprete y nuevo escritor del mensaje literario.

En la Primera Jornada examinará la naturaleza de un talento doble, el de Juan del Encina -cuyo famoso villancico "Más vale trocar" inaugura este estudio-, intérprete de si mismo, y analizará con detalle los recursos musicales dispuestos bajo la superficie de sus propios textos, así como el contexto teórico propiciado por la preceptiva del momento Marcos Durán o Juan Gil de Zamora-, la cual explicará el contexto sonoro de las obras propuestas. Con notable celo y, especialmente, con profunda pasión, recorrerá el autor la pervivencia de las composiciones encinianas en el teatro inmediatamente subsiguiente Códice de Autos Viejos o Cervantes-, así como en la recuperación que hizo de su figura el siglo XX, desde la generación de plata hasta el último Enrique Morente en el siglo ya XXI. Este intenso recorrido constituye un auténtico despliegue de análisis de aquellas composiciones de la mano de casi una veintena de autores que tomaron decisiones compositivas sobre la obra del sacerdote salmantino -desde Martínez Torner a Paco Ibáñez, pasando por Falla, Martín Pompey, Alonso Gómez o Cristóbal Halffter.

La Segunda Jornada prolongará el examen de la poesía de cancionero, especialmente la conservada en el Cancionero Musical de Palacio en la mirada del postromanticismo alemán, especialmente en el Spanisches Liederbuch de Hugo Wolf. Este análisis revela sorprendentes coincidencias de la escritura melódica ante las puertas del desmoronamiento de la tonalidad con aquella cuyo nacimiento desconocía y que se sitúa en los albores de siglo XVI. En este sentido, no solo Wolf, sino Schumann, Brahms, Schuberth o Sjögren son citados a colación de sus reflexiones musicales sobre el patrimonio lírico y poético español.

La Tercera Jornada resulta de un interesante desarrollo por cuanto se dedica a uno de nuestros poetas renacentistas desigualmente desatendidos pero con importantes vínculos con la realidad musical de su momento, especialmente la italiana. Nos referimos a Gutierre de Cetina, cuyos versos manifiestan la herencia de una poesía petrarquista cantada que se hace evidente no solo en su formación musical confesa, sino en la escucha y recepción de las composiciones de Lasso, Marenzio, Andrea Gabrielli, Philippe de Monte, Antonio Formica, Caludio Merulo o Francesco Lambardi. Las composiciones musicales recuperadas en una especie de arqueología musical del verso revelan un acervo musical que impregna el cultural y filosófico siempre subrayado por una crítica filológica que, sin embargo, desatiende la resonancia de la poesía cantada en la propia recepción y creación literaria.

La Cuarta Jornada se dedica a la lírica gongorina, centrándose en el desarrollo musical del romance Por las faldas del Atlante. Tributario y reconocedor de los trabajos de Querol, este capítulo ofrece una especial perspectiva que comunica la estructuración musical de los recursos fónicos y estilísticos del poema con las realizaciones que examina, atendiendo 
especialmente a la configuración dramática de una lírica permeable a los conceptos diseminados por la retórica y la oratoria. Pastor no solo confirma la existencia de una producción poética nacida para su ejecución en el canto -algo que transforma, en cierto modo, la comprensión genética de una lírica no escritural sino sonora-, sino que estudia cómo la forma musical propuesta por Gabriel Díaz satisface y renueva voz poética del vate cordobés.

La Quinta y última Jornada se ocupa del dramaturgo toledano Francisco de Rojas Zorrilla, en cuya reciente edición filológica participó el autor y en cuyas obras explora el valor del componente musical tanto desde una perspectiva organológica como folklórica y temática. Sorprende, sin embargo, el cuidadoso análisis que hace de una de sus tragedias, Progne y Filomena, de larga tradición en los cantos tradicionales y sefardíes hispanos, con notables paralelos en la Europa áurea. El estudio de las fuentes musicales e iconográficas y la traducción dramática que el hombre de teatro realiza sobre la escena permite a Pastor esbozar las directrices que atraviesan el espectáculo dramático para su alcanzar su comprensión cabal, íntimamente ligada al vínculo entre música, imagen y palabra.

La obra culmina con un sugerente "Fin de viaje" que no es sino una pausa en el camino de lo inefable. San Isidoro corona con su máxima "sine musica nulla disciplina potest esse perfecta", no tanto como la reivindicación de la primacía del arte que nos ocupa sino, antes bien, como irrenunciable exigencia de aproximar la articulación sonora a la comprensión de la palabra encarnada en altura, textura, dinámica, timbre y ritmo. Cierra el estudio una amplia y exhaustiva bibliografía que en todo momento se rinde pertinente y que alcanza en los últimos trabajos recogidos hasta el año en curso de su publicación.

Nos hallamos, en definitiva, ante una propuesta no solo novedosa por la riqueza de sus contenidos sino, muy especialmente, extraordinariamente bien articulada por la inteligencia de su método. No exenta de cierto desapego con el ámbito académico -sucede así en algunas veladas referencias a los comportamientos poco honestos que se pretenden "novo sub sole" - se erige, sin embargo, como modelo inimitable de un valioso hacer ilustrado. Sobre la base de una sólida documentación el autor nos expone -y al tiempo persuade- de cómo las realidades musicales y literarias no son solo vecinas, sino que se diluyen en los productos artísticos como una amalgama de tinturas, un enriquecimiento tímbrico o una tela inextricable que no puede contemplarse desde una sola perspectiva. Por esta razón, y por el tiento y la paciencia que toma en situarnos sobre la lupa del teórico literario, del musicólogo, del intérprete, del compositor, del aprendiz a escritor o del dramaturgo reconocido, las páginas de este libro son una inapreciable pauta para adentrarse sin temor y con las alforjas necesarias en la selva interdisciplinar del patrimonio poético y musical de la España moderna.

María Teresa Navarro Amador

Universidad de Castilla-La Mancha 